\title{
EFFECT OF PLANT SPACING AND NK FERTILIZATION ON VEGETATIVE GROWTH AND FLOWER PRODUCTION OF Helichrysum bracteatum Andr. PLANT
}

(Received:4.10.2010)

\author{
By \\ E.M.Badawy, S.M.Nicola, M.M.Farahat* and D.M.Soliman* \\ Ornamental Horticulture Department, Faculty of Agriculture, Cairo University, Giza, Egypt. \\ * Ornamental Plants and Woody Trees Department, National Research Center, Dokki. Giza, Egypt.
}

\begin{abstract}
Two field experiments were carried out at the Agricultural Experiment and Research Station, Faculty of Agriculture, Cairo University, Giza during 2006-2007 and 2007-2008 seasons to study the effect of plant spacing, nitrogen and potassium fertilization on the vegetative growth and flower production of strawflower plant (Helichrysum bracteatum Andr.).Planting space treatments were 20, 30 and $40 \mathrm{~cm}$. Fertilization treatments by using ammonium nitrate $(33.5 \% \mathrm{~N})$ at the rates of 100,150 and $200 \mathrm{Kg} / \mathrm{fed}(\mathrm{N} 1$, $\mathrm{N} 2, \mathrm{~N} 3$, respectively) and potassium sulphate $\left(48 \% \mathrm{~K}_{2} \mathrm{O}\right)$ at the rates of 50 and $75 \mathrm{Kg} / \mathrm{fed}(\mathrm{K} 1, \mathrm{~K} 2$, respectively), in addition to the control. The results indicated that the highest values for plant height, the number of branches and inflorescence diameter were obtained for planting distance at $40 \mathrm{~cm}$, while the maximum values for fresh and dry weights of plant and leaves were obtained for plants at $30 \mathrm{~cm}$.The application of NK treatment increased plant height, the number of branches, fresh and dry weight of leaves and plant and flower diameter of strawflower as compared with the control. Interaction between plant spacing and NK resulted in the maximum values for the number of branches/plant and inflorescence diameter cultivated at $40 \mathrm{~cm}$ apart with the application of $200 \mathrm{~kg}$ ammonium nitrate and $75 \mathrm{~kg}$ potassium sulphate.
\end{abstract}

Key words: Helichrysum bracteatum, nitrogen fertilizer, plant spacing, potassium (potash) fertilizer, strawflower.

\section{INTRODUCTION}

Annual flowering plants are very important in the garden landscaping in Egypt as other regions. Strawflower is considered hardy annual or ever lasting (Helichrysum bracteatum Andr.).Family Asteraceae is an easy annual plant to grow given different colored flower heads. It is endemic to Australia, growing in open scrub and grassland areas. The true petals are found in the center of each flower and they are surrounded by colorful, straw like bracts. The flowers bloom late in winter to summer. The flowers are harvested for drying before fully opening and used in dried arrangements, they open fully. Seed needs light to germinate, plant in porous soil. Proper nutrition of these plants is important to produce abundant flowers of adequate size and color intensity with good lasting qualities. Nitrogen $(\mathrm{N})$ plays a pivotal role in many critical functions (such as photosynthesis) as well major component of amino acids, which affect forming protoplasm, the site of cell division and plant growth. It is necessary for enzymatic reactions in plants, since all plant enzymes are proteins. Moreover, it is a necessary component of several vitamins, e.g., biotin, thiamine, niacin and riboflavin and the nucleic acids (DNA and RNA).Potassium (or Potash) plays roles in regulating the opening and closing of stomata and water retention. It promotes the growth of meristematic tissues activating some enzymatic reactions, aids in nitrogen metabolism, and the synthesis of proteins, catalyzes activities of some mineral elements, and aids in carbohydrate metabolism and translocations (Bhandal and Malik, 1988). Vegetative growth and flowering are affected with plant spacing, nitrogen and potassium fertilizers. Venugopal and Patil (2000) showed that the plant height,number of branches and leaves/plant were generally highest with $200 \mathrm{~kg} \mathrm{~N} / \mathrm{ha}$ of everlasting. El-Abagy(2002) showed that the branches number and dry weight of Helianthus annuus L. plant were increased with NP combined with K. Jitendra and Pranav(2003) found that plant height and the number of branches/plant were the highest with $300 \mathrm{Kg} \mathrm{N} / \mathrm{ha}$ treatment of varnation. Mili and Sable (2003) found that the number of leaves and branches, and leaf area increased with increasing planting density of Claendula officianlis L. $\mathrm{Kll}(2004)$ found that the head diameter increased 
with the lowest plant population of Helianthus annuus L. Gaikwad et al.(2004) found that the N rate $200 \mathrm{Kg} / \mathrm{ha}$ resulted in the grentest flower diameter, number and weight of flowers per plant in china aster. Ekwu and Mbah(2007) concluded that the highest flower diameter was achieved with the application of all nitrogen levels and $50 \mathrm{ppm}$ $\mathrm{K}$, while the highest number of flowers was produced by marigold at $100 \mathrm{ppm} \mathrm{K}$, for all nitrogen levels. Deepa et al.(2008) recorded that taller plants and greater number of branches were obtained at the spacing of with $45 \times 30 \mathrm{~cm}$ of China aster.

The objective of the present study was to find out the effect of plant spacing and NK fertilization treatments on the vegetative growth and flowering of strawflower.

\section{MATERIALS AND METHODS}

Two field experiments were carried out at the Agricultural Experiment and Researceh Station, Faculty of Agriculture, Cairo University, during 2006-2007 and 2007-2008 seasons to study the effect of plant spacing and NK fertilization on growth and flowering of Helichrysum bracteatum Andr. Seedlings were obtained from the Department of Ornamental Plants and Woody Trees, National Research Centre, Giza, Egypt. In the first week of November in both seasons, uniformed seedlings $(18-20 \mathrm{~cm}$ height $)$ of Helichrysum bracteatum were transplanted using 2 seedlings/hill, and thinned for one plant/hill after 30 days from transplanting. The layout of the experiment was split plot design, including twenty one treatments, which were the combinations between three plant spacing and seven fertilization treatments. Three replicates were carried out for each treatment giving 63 plots. Plant spacing was designed as the main plot with three distances between plants along the row 20,30 and $40 \mathrm{~cm}$ apart. NK fertilization treatments were the subplots and were in combination between ammonium nitrate $(33.5 \% \mathrm{~N})$ at the rates of 100,150 and $200 \mathrm{Kg} / \mathrm{fed}$ (N1,N2,N3,respectively) and potassium sulphate $(48 \% \mathrm{~K} 2 \mathrm{O})$ at the rates of 50 and $75 \mathrm{Kg} / \mathrm{fed}$ ( $\mathrm{K} 1, \mathrm{~K} 2$, respectively). The fertilization treatments were as follows: N1K1, $\mathrm{N} 2 \mathrm{~K} 1, \mathrm{~N} 3 \mathrm{~K} 1, \mathrm{~N} 1 \mathrm{~K} 2, \mathrm{~N} 2 \mathrm{~K} 2$ and N3K2 in addition to the control. Ammonium nitrate and potassium sulphate were added in two equal doses. The first dose was added after 45 days from transplanting, whereas the second part was added three weeks later. Calcium superphosphate $\left(15.5 \% \mathrm{P}_{2} \mathrm{O}_{5}\right)$ at the rate of $100 \mathrm{Kg} / \mathrm{fed}$ was applied before planting. Plot area was $5.25 \mathrm{~m}^{2}(2.1 \mathrm{~m}$ in width and $2.5 \mathrm{~m}$ in length) containing three rows; the distance between rows was $70 \mathrm{~cm}$. The plants received normal agricultural practices whenever needed.

\subsection{Growing medium}

The physical and chemical properties of the experimental field soil are presented in Table (1 and 2).The soil is classified as a sandy loam.

\subsection{Data recorded}

The following data were recorded at the $3^{\text {rd }}$

Table (1): Physical analysis of the sample taken from the experimental soil.

\begin{tabular}{|c|c|c|c|c|}
\hline Sample & Clay & Silt\% & $\begin{array}{c}\text { Sand } \\
\%\end{array}$ & Texture \\
\hline At 15 cm depth & 14.54 & 30.00 & 55.26 & $\begin{array}{c}\text { sandy } \\
\text { loam }\end{array}$ \\
\hline At 30 cm depth & 14.90 & 29.78 & 55.29 & $\begin{array}{c}\text { sandy } \\
\text { loam }\end{array}$ \\
\hline
\end{tabular}

week of April 2006 and 2008:

1-Plant height $(\mathrm{cm})$.

2 -Number of branches/plant.

3-Fresh and dry weights of plant (g).

4- Fresh and dry weights of leaves/plant (g).

5- Number of sprays/plant.

6- Number of inflorescences/ spray.

7-Inflorescence diameter $(\mathrm{cm})$.

The differences between the means of the different treatments of each experiment were compared by using L.S.D test at 5\% probability (Snedecor and Cochran, 1980).

\section{RESULTS AND DISCUSSION \\ 3.1.Plant height}

The data illustrated in Table (3) show the plant height as affected by plant spacing and NK fertilization.

In both seasons, significant differences between the three distances were obtained. The tallest plants were spaced at $40 \mathrm{~cm}$ apart, while, the shortest ones were obtained at $20 \mathrm{~cm}$ apart

Table (2): Chemical analysis of the sample taken from the experimental soil.

\begin{tabular}{|c|c|c|c|c|c|c|c|c|c|c|c|}
\hline \multirow{3}{*}{$\begin{array}{l}\text { Soil } \\
\text { depth }\end{array}$} & \multirow{3}{*}{$\begin{array}{c}\text { S.P. } \\
\%\end{array}$} & \multirow{3}{*}{$\begin{array}{c}\mathrm{CaCo}_{3} \\
\%\end{array}$} & \multirow{3}{*}{$\mathbf{p H}$} & \multirow{3}{*}{$\underset{\text { mmhos }}{\text { Ec }}$} & \multicolumn{7}{|c|}{ Mill equivalent/Liter } \\
\hline & & & & & \multicolumn{4}{|c|}{ Cations } & \multicolumn{3}{|c|}{ Anions } \\
\hline & & & & & $\mathrm{Ca}^{++}$ & $\mathrm{Mg}^{++}$ & $\mathrm{Na}^{+}$ & $\mathrm{K}^{+}$ & $\mathrm{CO}_{3}^{-}$ & $\mathrm{HCO}_{3}{ }^{-}$ & $\mathrm{Cl}^{-}$ \\
\hline $15 \mathrm{~cm}$ & 52.6 & 8.12 & 8.20 & 2.54 & 8.5 & 6 & 10.9 & 0.6 & Nil & 2.6 & 10.5 \\
\hline $30 \mathrm{~cm}$ & 51.9 & 7.75 & 8.28 & 2.96 & 10 & 7 & 12.3 & 0.6 & Nil & 3.85 & 9.5 \\
\hline
\end{tabular}


spacing. These results are in accordance with those obtained by Mili and Sable (2003) on Calendula officinalis L. and Deepa et al. (2008) on China aster; they reported that the plant height tended to increase by widening the distances between plants.

In both seasons, all NK treatments significantly increased the plant heights compared to the untreated plants. The tallest plants were obtained in the two seasons produced from N2K2 treatment. Generally, raising both $\mathrm{N}$ and $\mathrm{K}$ levels increased the plant height. The shortest plants were obtained from N1 K1. These findings are in agreement with the results of Gaikwad et al. (2004) on China aster. They found that plant height increased with increasing nitrogen level.

The interaction between plant spacing and fertilization levels showed that, in both seasons, all fertilization levels significantly increased the plant height when the plants were grown at 20, 30 or $40 \mathrm{~cm}$ distances as compared to the control. The greatest effect was produced from using the combination between $\mathrm{N} 2 \mathrm{~K} 2$ treatment with $30 \mathrm{~cm}$ spacing treatment.

\subsection{Number of branches/plant}

The data shown in Table (3) on the number of branches/plant as affected by plant spacing and NK fertilization reveal that this character was significantly affected by the different plant spacing. The greatest number of branches/plant in both seasons was obtained from $40 \mathrm{~cm}$ apart spacing, while the least number of branches was found on plants spaced at $20 \mathrm{~cm}$ apart. This means that wider space gave the plants the opportunity to enhance branching, while narrow distance inhibits the capability of the plants for producing more branches. These findings are in agreement with those obtained by Zayed et al. (2003) on Borago officinalis and Deepa et al. (2008) on China aster. They reported that the number of branches/plant was increased as plant spacing became wider, and this may be due to that the increase in spacing would permit more space for more water and available nutrients that result in a good plant growth leading to more branches/plant.

The greatest mean values for the number of branches/plant in the two successive seasons $(16.64$ and $18.60 \mathrm{~cm})$ resulted from treating the plants with N3K2. While, those treated with N1K1 had the least value for the number of branches/plant, but higher than the control. In the two seasons, increasing potassium level from K1 to $\mathrm{K} 2$ in $\mathrm{NK}$ mixture with the three levels of nitrogen gradually increased branches/plant, except in the second one, the trend was observed only with the high level of potassium (K2). The results are in conformity with those obtained by Attia and Ahmed (1997) on Chrysanthemum morifolium; Abdou and El Sayed (2002) on Carum carvi, L. and Abd El-Azim (2003) on Salvia officinalis, who found that increasing the N levels increased the number of branches/plant.

The treatments with plant spacing and NK fertilizer revealed that there was a positive interaction between the two factors resulting in additional increasing in the number of branches/plant as compared with the control. In both seasons, the data pointed out that N3K2 combined with the wider space $(40 \mathrm{~cm})$ was the most effective treatment in increasing the number of branches/plant.

\subsection{Fresh and dry weights of the plant}

The data in Table (4) show the plant fresh and dry weight of Helichrysum bracteatum as affected by plant spacing and fertilizer treatments. It is clear that there was significant effect of the different treatments in both seasons; the highest value for fresh and dry weight plant in the first season was obtained from plants spaced at $30 \mathrm{~cm}$ apart. However, wider spacing $(40 \mathrm{~cm}$, apart) produced the heaviest plant dry weight in the second season. The close spacing $(20 \mathrm{~cm})$ gave the lowest values of plant fresh and dry weight in the two seasons. These results agree with the findings obtained by many investigators; Abd El Salam (1994) and (1999) on Pimpinella anisum; Hafez (1998) on Nigella sativa and Poonia (2000) on sunflower. They reported that the wider and medium spacing produced the highest plant fresh and dry weights.

The low level of nitrogen (N1) combined with the low or high level of potassium (K1) or (K2) produced the highest values of plant fresh and dry weights in both seasons. In the first season, the lowest value of plant fresh and dry weights were obtained from plants received N3K1 fertilizer while, in the second one was from the application of N2K1. The obtained results are in harmony with those of Abd El-Azim (2003) on Salvia officinalis and Ekwu and Mbah (2007) on Tagetes erecta $\mathrm{L}$. who found that high nitrogen and low potassium levels reduced the fresh and dry weights of the plants.

All combination treatments between plant spacing and NK fertilizer increased significantly plant fresh and dry weights as compared to unfertilized plants at any plant spacing in the two 
Table (3): Effect of plant spacing and NK fertilization on plant height and stem diameter of Helichrysum bracteatum during 2006/2007 and 2007/2008.

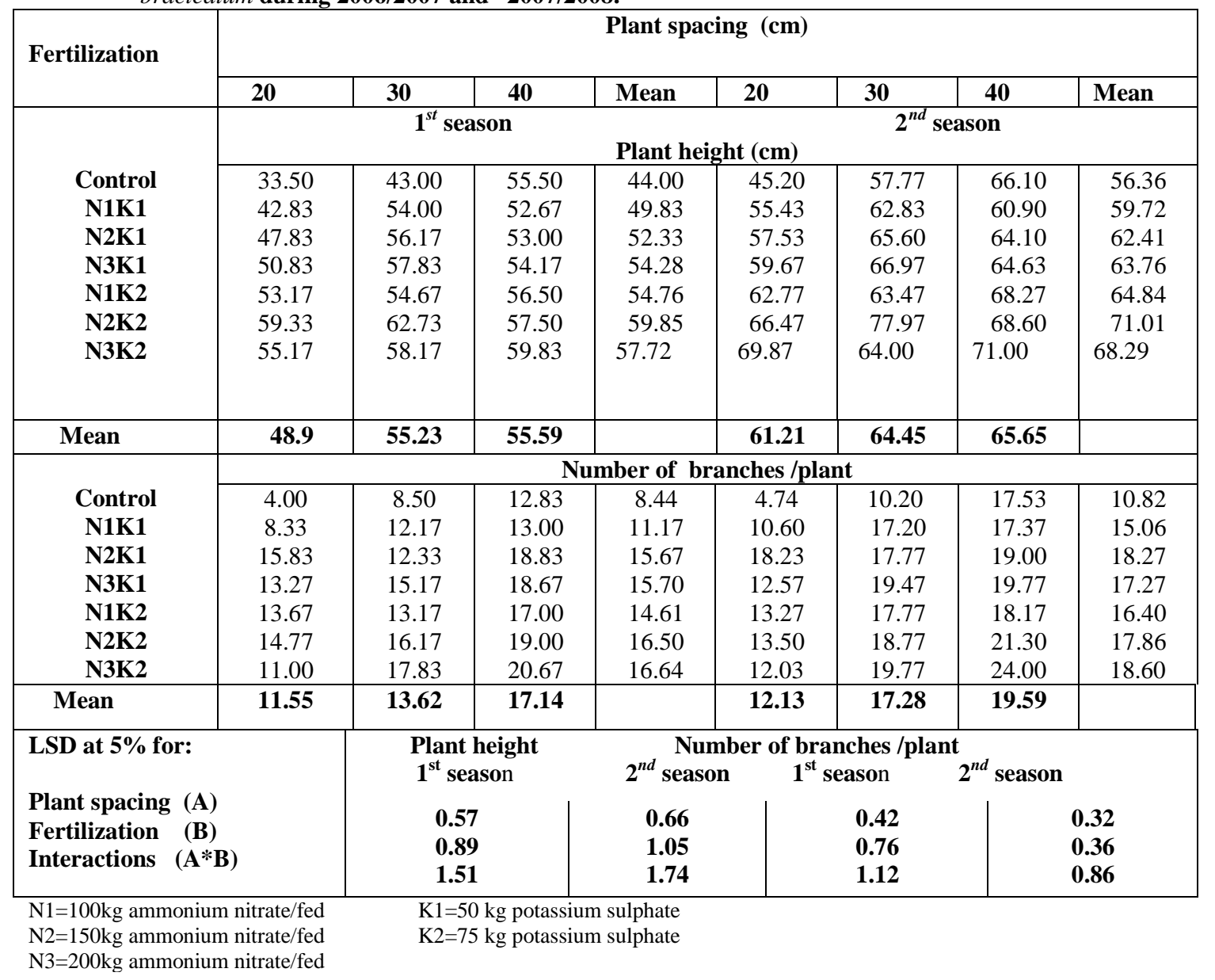

Table (4): Effect of plant spacing and fertilization on fresh and dry weight of Helichrysum bracteatum during 2006/2007and 2007/2008.

\begin{tabular}{|c|c|c|c|c|c|c|c|c|}
\hline \multirow{2}{*}{ Fertilization } & \multicolumn{8}{|c|}{ Plant spacing (cm) } \\
\hline & 20 & 30 & 40 & Mean & 20 & 30 & 40 & Mean \\
\hline \multirow{8}{*}{$\begin{array}{c}\text { Control } \\
\text { N1K1 } \\
\text { N2K1 } \\
\text { N3K1 } \\
\text { N1K2 } \\
\text { N2K2 } \\
\text { N3K2 }\end{array}$} & \multicolumn{3}{|c|}{$\mathbf{1}^{\text {st }}$ season } & \multicolumn{5}{|c|}{$2^{n d}$ season Fresh weight of plant $(\mathrm{g})$} \\
\hline & 121.9 & 176.6 & 221.5 & 174.3 & 189.5 & 281.7 & 335.9 & 269.0 \\
\hline & 333.5 & 592.8 & 993.1 & 639.8 & 509.5 & 900.1 & 998.3 & 802.6 \\
\hline & 232.5 & 734.7 & 369.1 & 445.4 & 400.9 & 924.0 & 628.1 & 651.0 \\
\hline & 329.0 & 470.0 & 442.7 & 413.9 & 463.2 & 835.1 & 683.1 & 660.5 \\
\hline & 363.3 & 940.7 & 877.2 & 727.2 & 614.4 & 990.0 & 986.9 & 863.8 \\
\hline & 248.2 & 865.1 & 417.7 & 510.3 & 432.5 & 926.9 & 634.9 & 664.8 \\
\hline & 324.2 & 710.6 & 425.5 & 486.8 & 442.5 & 904.4 & 678.3 & 675.1 \\
\hline \multirow[t]{2}{*}{ Mean } & 278.9 & 641.9 & 535.3 & & 436.1 & 823.2 & 706.5 & \\
\hline & \multicolumn{8}{|c|}{ Dry weight of plant (g) } \\
\hline Control & 33.1 & $49 . .0$ & 69.5 & 50.5 & 46.2 & 88.5 & 102.1 & 78.9 \\
\hline N1K1 & 109.2 & 134.5 & 212.9 & 152.2 & 135.4 & 170.9 & 332.5 & 212.9 \\
\hline N2K1 & 79.0 & 168.2 & 117.00 & 121.4 & 103.1 & 174.5 & 154.5 & 144.0 \\
\hline N3K1 & 86.6 & 132.3 & 130.7 & 116.5 & 115.1 & 166.6 & 163.8 & 148.5 \\
\hline N1K2 & 111.9 & 192.2 & 187.7 & 163.9 & 148.2 & 276.6 & 240.9 & 221.9 \\
\hline N2K2 & 83.1 & 175.1 & 117.2 & 125.1 & 112.3 & 180.0 & 161.2 & 151.2 \\
\hline N3K2 & 85.8 & 141.6 & 118.1 & 115.2 & 114.9 & 172.7 & 163.1 & 150.2 \\
\hline Mean & 84.1 & 141.8 & 126.2 & & 110.7 & 175.7 & 188.3 & \\
\hline \multirow{2}{*}{\multicolumn{2}{|c|}{$\begin{array}{l}\text { LSD at } 5 \% \text { for: } \\
\text { Plant spacing }(\mathbf{A}) \\
\text { Fertilization }(\mathbf{B}) \\
\text { Interactions } \quad(\mathbf{A} * \mathbf{B})\end{array}$}} & \multicolumn{7}{|c|}{ Fresh weight of plant (g) $\quad$ Dry weight of plant (g) } \\
\hline & & \multicolumn{2}{|c|}{$\begin{array}{l}0.61 \\
0.85 \\
1.61\end{array}$} & $\begin{array}{l}0.59 \\
1.23 \\
1.55\end{array}$ & & $\begin{array}{l}0.61 \\
0.85 \\
1.61\end{array}$ & & $\begin{array}{l}.59 \\
1.23 \\
1.55\end{array}$ \\
\hline
\end{tabular}


seasons. Plant spacing at $40 \mathrm{~cm}$ apart combined with N1K1 fertilizer resulted in the heaviest plant fresh and dry weights in both seasons, respectively.

\subsection{Fresh and dry weights of leaves}

The data on the average fresh and dry weights of leaves are presented in Table (5) and reveal that; in the two seasons, the heaviest fresh weight of leaves (152.3 and $150.1 \mathrm{gm}$ ) was obtained from the plants spaced at $30 \mathrm{~cm}$ apart, followed by the distance of $40 \mathrm{~cm}$ apart, (122.0 and $116.6 \mathrm{gm})$, while, the closer spacing $20 \mathrm{~cm}$ apart produced the lowest value for fresh and dry weights of leaves (118.6 and $114.7 \mathrm{gm})$ for the $1^{\text {st }}$ and $2^{\text {nd }}$ season ,respectively . Zaied et al. (1990) on Cassia acutifolia; Ahmed (1997) on Nigella sativa and Zayed et al. (2003) on Borago officinalis reported similar trends.

Concerning the dry weight of leaves, it was found that the heaviest values of dry weight (42.5 and $36.4 \mathrm{gm}$ ) were obtained from the plants at 30 $\mathrm{cm}$ spacing in both seasons. There was insignificant difference in dry weights of leaves between plant spacing at $20 \mathrm{~cm}$ and $40 \mathrm{~cm}$ apart in the two seasons.

Data in Table (5) reveal that all rates of NK fertilization had significant effect on fresh and dry weight of Helichrysum bracteatum in the two seasons as compared to untreated plants. Fresh and dry weight of leaves were positively affected by the application of high levels of nitrogen and potassium fertilizers in the two seasons. Similar results were reported by Ali et al. (1994) on Coriandrum sativum L.; El- Fadaly (1994) on Jasminum sambac and Abd El -Azim (2003) on Salvia officinalis.

All NK fertilization treatments under any plant spacing significantly increased fresh and dry weights of leaves/plant as compared with the control in the two seasons. The heaviest fresh and dry weights of leaves/plant resulted from the plants cultivated at $30 \mathrm{~cm}$ distance and received $\mathrm{N} 3 \mathrm{~K} 2$ rate of fertilizer.

\subsection{Number of sprays/plant}

The data in Table (6) show the number of sprays/plant as affected by plant spacing and fertilization and revealed that this character was affected by the different plant spacing. In the two seasons, there was significant effect of plant spacing on this character; the highest number of sprays/plant(14.86 and 16.67) was recorded for plants spaced at $40 \mathrm{~cm}$ apart, while the lowest number (11.05 and 12.76) was obtained at $20 \mathrm{~cm}$ distance. Similar results were observed by Radwan (1980) on Caraway and Balyan et al. (1990) on Celery. They found that increasing the distance between plants resulted in continuous increase in the umbels/plant.

Increasing nitrogen and potassium levels in NK mixture gradually increased number of sprays/plant. So, the highest number of sprays /plant (18.0 and 19.67) resulted from the plants fertilized with $\mathrm{N} 3 \mathrm{~K} 2$ in the two seasons, respectively. However, fertilizing the plants with N1K1 produced the lowest number sprays /plant (7.56 and 10.11) for the two seasons, respectively, but higher than the control. The high level of both $\mathrm{N}$ and $\mathrm{K}(3: 2)$ was the most effective treatment in increasing the number of spray/plant; this rate of NK fertilizer doubled the spray number/ plant in comparison with the control. Similar results were found by Abdou and El- Sayed (2002) on Carum carvi L. and Kumar et al., (2008) on coriander, who showed that increasing the rate of NK fertilizer resulted in continuous increase in the number of umbels/plant.

Plant spacing at $40 \mathrm{~cm}$ apart and fertilized with N3K2 produced the highest number of sprays/plant (20.33 and 21.67) for the two successive seasons as compared to any other treatment and the control followed by plant spacing at $30 \mathrm{~cm}$ apart with $\mathrm{N} 3 \mathrm{~K} 2$ fertilization .The lowest values of spray number/plant (8.33 and 10.67) resulted from the closer space $(20 \mathrm{~cm})$ combined with N1K1 fertilizer in the two seasons, and less than the control.

\subsection{Number of inflorescences/ spray}

Data in Table (6) illustrate the number of inflorescences/spray in response to plant spacing and fertilization treatments and revealed that there was significant effect of plant spacing and NK fertilization on this character in both seasons.

In both seasons, the highest number of inflorescences /spray (3.67 and 3.51) was obtained from the plants at wider spacing $(40 \mathrm{~cm})$, while the closer spacing $(20 \mathrm{~cm})$ resulted in the lowest number of inflorescences /spray (3.16 and 3.07) for the $1^{\text {st }}$ and $2^{\text {nd }}$ seasons, respectively . Similar results were observed by Bianco et al. (1994) on fennel and Abd- El-Latif (1999) on anise.

In both seasons, the highest number of inflorescences/spray resulted from the plants fertilized with N1K2 rate. In the first season, applications of $\mathrm{N} 2 \mathrm{~K} 1$ treatment resulted in the lowest number of inflorescences /spray, while supplying the plants with $\mathrm{N} 1 \mathrm{~K} 1$ produced the lowest number of inflorescences/spray but less than the control in both seasons. In the first season, the comparison between the three nitrogen levels with a high level of potassium (K2) caused no significant differences in inflorescences number/spray. Similar results were observed by 
Table (5): Effect of plant spacing and fertilization on leaf fresh and dry weights of Helichrysum bracteatum plant during 2006/2007 and2007/2008.

\begin{tabular}{|c|c|c|c|c|c|c|c|c|}
\hline \multirow[t]{2}{*}{ Fertilization } & \multicolumn{8}{|c|}{ Plant spacing (cm) } \\
\hline & 20 & 30 & 40 & Mean & 20 & 30 & 40 & Mean \\
\hline \multirow{3}{*}{$\begin{array}{c}\text { Control } \\
\text { N1K1 }\end{array}$} & \multicolumn{3}{|c|}{$\mathbf{1}^{s t}$ season } & \multicolumn{5}{|c|}{$\begin{array}{l}2^{\text {nd }} \text { season } \\
\text { Fresh weight of leaves }(\mathrm{g})\end{array}$} \\
\hline & 60.7 & 76.5 & 75.4 & 70.9 & 56.00 & 69.00 & 68.9 & 64.6 \\
\hline & 79.9 & 110.0 & 81.4 & 90.4 & 75.9 & 103.8 & 76.00 & 85.2 \\
\hline N2K1 & 115.4 & 151.6 & 119.8 & 128.9 & 104.7 & 157.7 & 118.3 & 126.9 \\
\hline N3K1 & 120.6 & 182.3 & 143.6 & 148.8 & 122.5 & 169.3 & 136.5 & 142.8 \\
\hline N1K2 & 115.7 & 161.5 & 133.5 & 136.9 & 111.3 & 157.8 & 126.2 & 132.1 \\
\hline N2K2 & 148.1 & 182.4 & 148.5 & 159.7 & 136.6 & 171.5 & 138.4 & 148.8 \\
\hline N3K2 & 189.6 & 201.8 & 151.6 & 181.0 & 195.7 & 220.5 & 152.2 & 189.5 \\
\hline \multirow[t]{2}{*}{ Mean } & 118.6 & 152.3 & 122.0 & & 114.7 & 150.1 & 116.6 & \\
\hline & \multicolumn{8}{|c|}{ Dry weight of leaves (g) } \\
\hline Control & 12.6 & 19.5 & 14.1 & 15.4 & 11.7 & 16.0 & 15.2 & 14.3 \\
\hline N1K1 & 20.5 & 25.3 & 24.8 & 23.5 & 16.1 & 19.5 & 16.8 & 17.5 \\
\hline N2K1 & 30.7 & 42.1 & 32.3 & 35.0 & 19.6 & 38.6 & 24.3 & 27.5 \\
\hline N3K1 & 34.4 & 51.7 & 36.9 & 41.0 & 24.7 & 39.2 & 27.7 & 30.5 \\
\hline N1K2 & 33.6 & 47.7 & 35.1 & 38.8 & 23.7 & 38.7 & 27.3 & 29.9 \\
\hline N2K2 & 37.8 & 52.3 & 38.9 & 43.0 & 30.9 & 40.9 & 35.9 & 35.9 \\
\hline N3K2 & 52.3 & 58.8 & 39.0 & 50.3 & 50.4 & 62.0 & 37.1 & 49.8 \\
\hline Mean & 31.7 & 42.5 & 31.6 & & 25.3 & 36.4 & 26.3 & \\
\hline LSD at $5 \%$ for: & \multicolumn{8}{|c|}{ Fresh weight of leaves(g) } \\
\hline & \multicolumn{5}{|c|}{$1^{\text {st }}$ season $\quad 2^{\text {nd }}$ season } & st seasor & $2^{\text {nd }} \mathrm{S}$ & \\
\hline $\begin{array}{l}\text { Plant spacing (A) } \\
\text { Fertilization (B) } \\
\text { Interactions }\left(\mathbf{A}^{*} \mathbf{B}\right)\end{array}$ & & $\begin{array}{l}1.02 \\
1.94 \\
2.69\end{array}$ & & $\begin{array}{l}0.84 \\
1.54 \\
2.23\end{array}$ & & $\begin{array}{l}1.84 \\
3.50 \\
4.86\end{array}$ & & $\begin{array}{l}.39 \\
.84 \\
.69\end{array}$ \\
\hline
\end{tabular}

Table (6): Effect of plant spacing and fertilization on the number of sprays/plant, number inflorescences/spray of Helichrysum bracteatum plant during 2006/2007 and2007/2008.

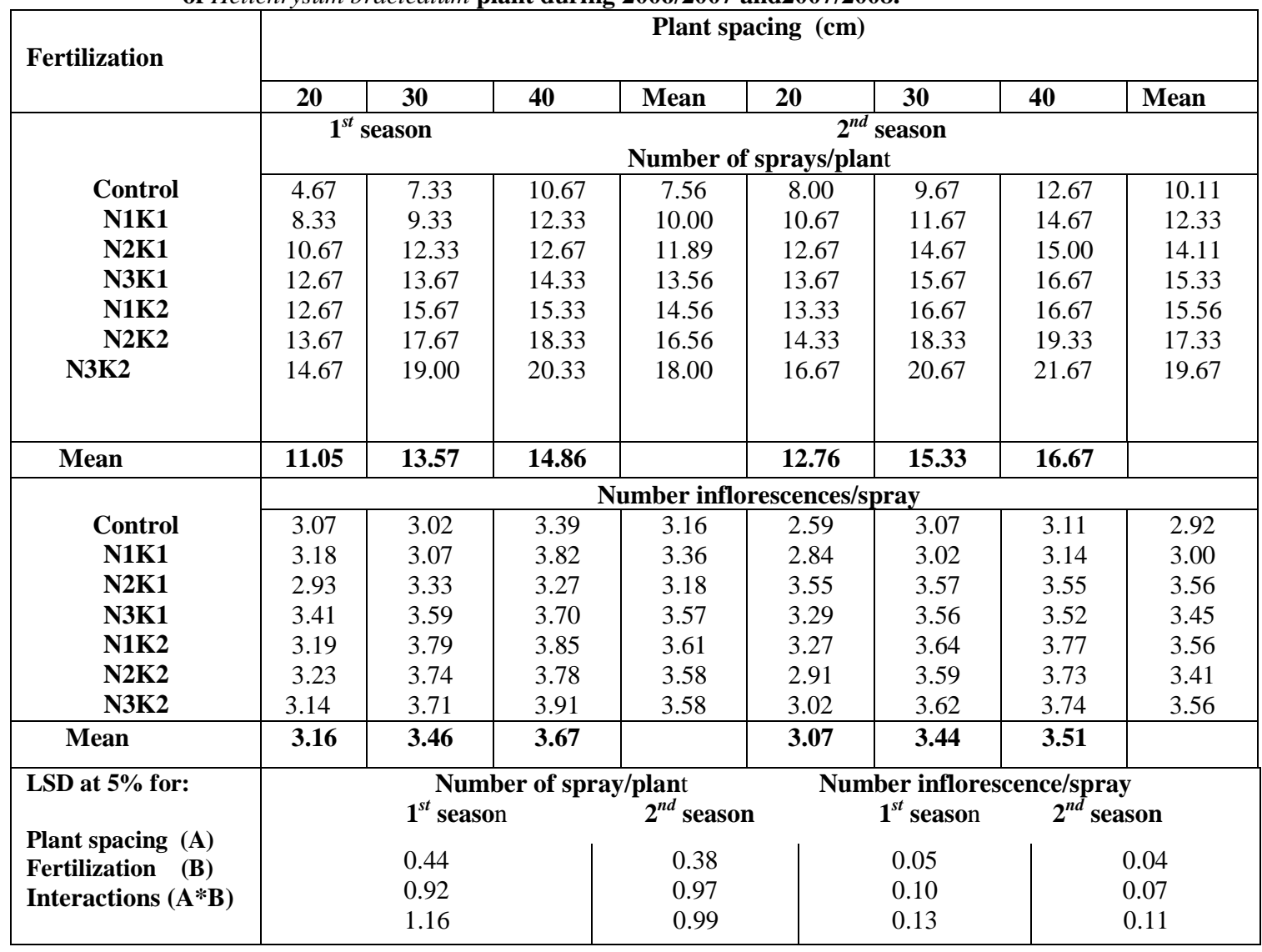


Table (7) Effect of plant spacing and fertilization on inflorescence diameter of Helichrysum bracteatum during 2006/2007 and2007/2008.

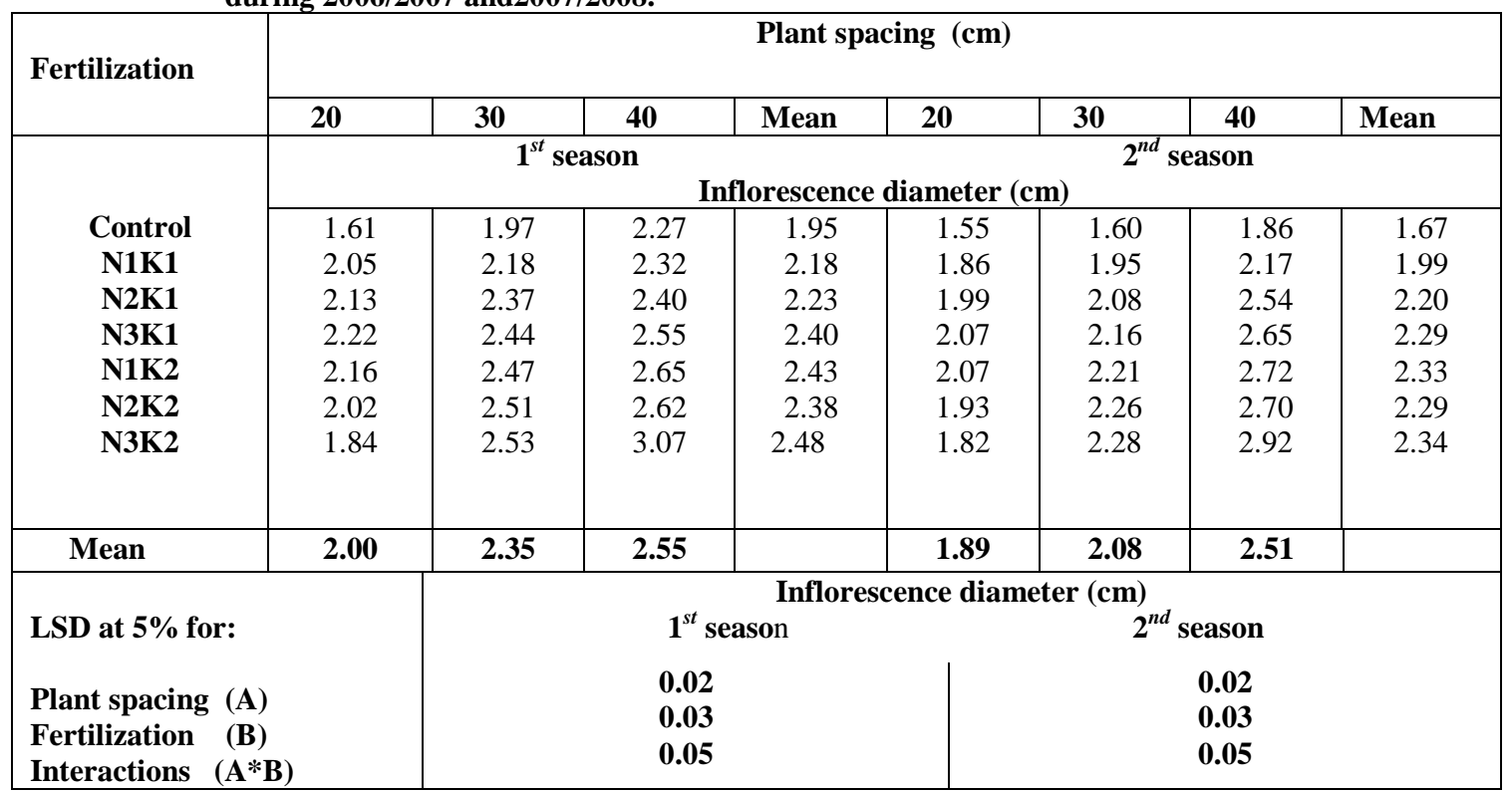

Soliman (1997) on Nigella sativa and Abd- ElLatif (1999) on anise.

In the first year, plant spacing at $40 \mathrm{~cm}$ apart with $\mathrm{N} 3 \mathrm{~K} 2$ fertilizer resulted in the greatest number of inflorescences/spray. In the second season, the plant fertilized with N1K2 under the wider space $(40 \mathrm{~cm})$ followed by those treated with $\mathrm{N} 3 \mathrm{~K} 2$ under the same distance (40 $\mathrm{cm}$ apart) produced the highest number of inflorescences /spray.

\subsection{Inflorescence diameter}

Table (7) shows data on the effect of plant spacing and fertilization on inflorescence diameter of Helichrysum bracteatum.

In both seasons, the greatest inflorescence diameter was obtained at $40 \mathrm{~cm}$ apart spacing, while the least value for inflorescence diameter was measured for plant at $20 \mathrm{~cm}$ spacing. The wider planting distance $(40 \mathrm{~cm})$ gave 27.4 and $32.3 \%$ higher than the closer spacing $(20 \mathrm{~cm})$ on inflorescences diameter. These findings are in agreement with those obtained by Jhon et al. (1991) on Zinnia elegans and Kll (2004) on sunflower. They indicated that the wider space increased flower diameter compared to the closer space.

In the first season, the highest value of inflorescence diameter was obtained from N3K2 fertilizer while, in the second one, N1K2 fertilizer gave the highest value of inflorescence diameter. In both seasons, the lowest value inflorescence diameter was obtained from N1K1 fertilizer rate, but higher than the unfertilized plants. This means that higher $\mathrm{N}$ levels are more positive on increasing the inflorescence diameter than low rate. The present findings are in harmony with those obtained by Chauhan and Kumar (2007) on
Calendula officinalis and Ekwu and Mbah (2007) on marigold. They showed that the highest flower diameter resulted from all nitrogen and potassium levels.

The largest inflorescence diameter resulted from treating the plants with plant spaced at $40 \mathrm{~cm}$ apart combined with $\mathrm{N} 3 \mathrm{~K} 2$ fertilizer rate in both seasons. However, the lowest values of inflorescence diameter were observed on the plants fertilized with $\mathrm{N} 3 \mathrm{~K} 2$ under the closer space $(20 \mathrm{~cm})$. This may be explained by that the plants at wider space had the conditions of building vigorous branches, stronger inflorescence and having large diameter. This means that the nutrient supply was sufficient for such growth and flowering.

It could be that Concluded the $40 \mathrm{~cm}$ between plants was the most effective treatment for increasing the plant height, the number of branches, inflorescence diameter and the number of spray /plant.

Interaction between plant spacing and NK resulted in the maximum values for the number of branches/plant, the number of spray/plant and inflore scence diameter cultivated at $40 \mathrm{~cm}$ apart with application of $200 \mathrm{~kg}$ ammonium nitrate and $75 \mathrm{~kg}$ potassium sulphate.

\section{REFERENCES}

Abd-El-Azim W.M. (2003). Production of Salvia officinalis, L. plant under Sinai conditions. Ph. D. Thesis, Fac. Agric., Cairo Univ., Egypt. Abd-El-Latif M.Z.(1999). Response of Pimpinella aninsum L. plants to planting density and phosphorus, zinc and manganese fertilization treatments. M.Sc.Thesis, Fac. of Agric., Minia Univ., Egypt. 
Abd El Salam, I.Z. (1994). Effect of chemical fertilization and planting distances on growth and chemical composition of Pimpinella anisum, L. plant. M.Sc. Thesis, Fac. Agric., Cairo Univ., Egypt.

Abd El Salam I.Z. (1999). Physiological study on Feoniculum vulgare, Mill plants. Ph. D. Thesis, Fac. Agric., Cairo. Univ., Egypt.

Abdou M.A. and El Sayed A.A. (2002). Effect of planting date and biofertilization treatments on growth and yield characters of Carum carvi. 1. Proc. $2^{\text {nd }}$ Hort. Sci. Conf., 10-12 Sept. 2002, Kafr El-Sheikh, Tanta. Univ., Egypt.

Ahmed E.T.(1997). Influence of plant density and some phosphorus fertilization sources on black cumin ( Nigella sativa, L.) plants. Assuit Journal of Agric. Sci. 28(2):39-56.

Ali S.A., Tomar R.K. and Maurya K.N. (1994). Response of coriander (Coriandrum sativum L.) to irrigation and nutrient levels, Bhartiya Krishi Anusandhan Patrika,9(4):241-246,(c.f. Hort. Abst.,66:4434).

Attia F.A. and Ahmed E.T.(1997). Influence of some nitrogen fertilization forms and two growth regulators on Chrysanthemum morifolium, Ramat c.v. Icecap. J. Agric. Sci. Mansoura. Univ., Egypt. 22(4): 1154-1159.

Balyan S. S., Chowdhary D.K. and Kaul B.L. (1990). Response of celery to different row spacings. India Perfumer, 34 (2):168-170.

Bhandal, I.S. and Malik, C.P. (1988). Potassium estimation, uptake, and its role in the physiology and metabolism of flowering plants. Intern. Review of Cytology 110: 205254.

Bianco V.V.,Damato G., Girardi A.,Quagliotti I. and Belletti P.(1994). Sowing dates, plant density and crown cutting on yield and quality of Florence fennel seed. International symposium on agrote chnics and storage of vegetable and ornamental seeds, Bari, Italy. Acta. Hort. No.362: 59-66.

Chauhan A and Kumar V. (2007). Effect of graded levels of nitrogen and Vam on growth and flowering in calendula ( Calendula officinalis, L.). Journal of Ornamental Horticulture, 10(1): 61-63.

Deepa S, Paramesh R, Reddy, D.M.V., Jayanthi R, Doss D.D. and Bal Krishna P.(2008).Effect of plant density and nutrition on seed production in China aster(Callistephus chinensis, L.) Nees. cv Poornima. Environment and Ecology., 26(3A): 1246-1249.

Ekwu L.G and Mbah B.N.(2007). Effect of nitrogen, potassium and media on the growth and flowering of Marigold (Tagetes erecta
L.). Journal of Agriculture, Food, Environment and Extension, 6(1):46-55.

El-Abagy H.M.H. (2002). Effect of nitrogen, phosphorus and potassium fertilization levels on plant growth, chemical composition, and yield of Jerusalem artichoke (Helianthus annuus L.). Annals of Agricultural Science, Moshtohor, 40 (3): 1755-1765.

El-Fadaly H.G. (1994). Effect of chemical fertilization and gibberllic acid (GA3) treatments on growth, flowering and chemical composition of Jasminum sambac L. plants M. Sc. Thesis, Fac. of Agric, Cairo Univ., Egypt.

Gaikwad S.A, Patil S.S.D and Patil .G.D. (2004). Effect of different levels of nitrogen and phosphorus on the growth and flower production of China aster (Callistephus chinensis L.) Nees. Journal of Maharashtra Agricultural Universities.29 (2): 140-142.

Hafez M.S.(1998). Effect of plant density, planting date ,nitrogen fertilization sources and some nutrients on growth ,flowering, seed yield and oil yield of Nigella sativa .L. plants. $\mathrm{Ph}$. D. Thesis, Fac. of Agric., Minia Univ., Egypt.

Jhon A.Q., Paul T.M. and Tanki M. I.(1991). Effect of nitrogen and plant spacing on growth and flower production of Zinnia elegans Tacq. Advanc. Plant, Sci, 4(1): 1-7 (c.f. Hort. Abst., 63:495).

Jitendra K. and Pranav R. (2003). Responses of nitrogen and IAA in spray carnation. Journal of Ornamental Horticulture (New series).6(3): 285-286.

Kll F.(2004).Influence of different nitrogen levels on productivity of oilseed and confection sunflowers( Helianthus annuus L.) under varying plant populations. International Journal of Agriculture and Biology, 6(4): 594598.

Kumar A., Singh R. and Chhillar R. K. (2008). Influence of omitting irrigation and nitrogen levels on growth, yield and water use efficiency of coriander (Coriandrum sativum L.).Acta Agronomica Hungarica., 56(1): 6974.

Mili R. and Sable A.S.(2003). Effect of planting density and nitrogen levels on growth and flower production of calendula (Calendula officinalis L.). Indian Journal of Horticulture., 60(4): 399-403.

Poonia K.L. (2000). Effect of planting geometry, nitrogen and sulfur on growth and yield of sunflower (Helianthus annuus, L.). Journal of Eco Physiology, 3(1/2): 59-71. 
Radwan A.A.S. (1980). Effect of some cultural treatments on the growth of some umbelliferae plants and their active constituents. M.Sc. Thesis, Fac. Agric. Ain Shams Univ., Egypt.

Snedecor C.W. and Cochran G.(1980).Statistical Methods. $6^{\text {th }}$ ed. Iowa State Univ., Press, Ames. Iowa, USA. 953 pp.

Soliman H.S. (1997). Influence of different phosphorus fertilization treatments and honey bee activities on Nigella sativa, plants. M. Sc. Thesis, Fac. of Agric., Minia Univ., Egypt.

Venugopal C.K. and Patil A.A. (2000).Effect of graded levels of nitrogen and plant population on growth and flower yield of everlasting flower. Karnataka Journal of Agricultural Sciences., 13(3): 692-696.

Zaied A.A., S. El-Deeb and Al-Masry M.H. (1990). Effect of plant spacing on growth , yield and active ingredients of Cassia acutifolia Delile plant. Minia J. Agric. Res. And Dev.,. 11(3): 1342-1356.

Zayed A.A., Sadek A.A. and Kandeel A.M. (2003). Effect of sowing dates and planting distances on borage (Borago officinalis, L.) plant. Egypt. J. Appl. Sci., 18(3): 263-285.

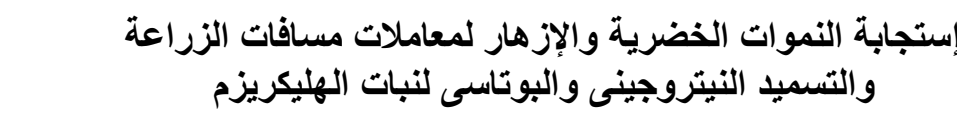

السعدى عحم بدوى - سعد ميلاد نقولا- محمود عحم فرحات*ـ دينا محمود سليمان

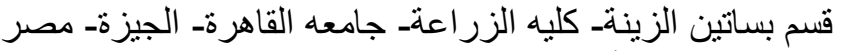

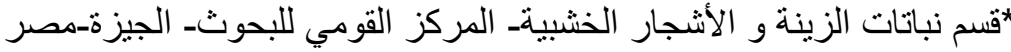

أقيمت تجربتان حقليتان فى مزر عة كليه الزر اعة- جامعة القاهرة خلال موسمي الزر اعة 2006-2007 و 2007-

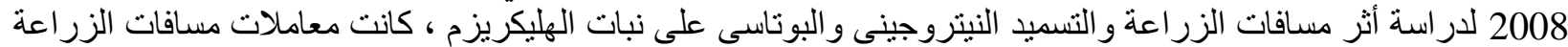

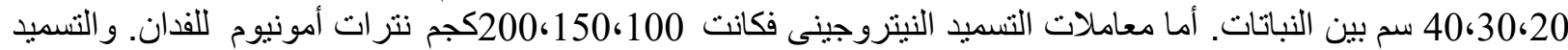

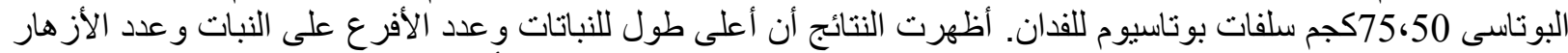

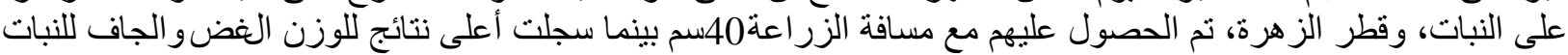

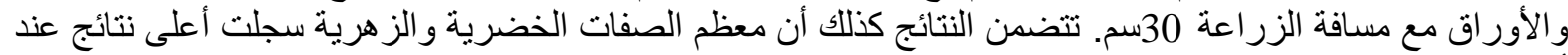

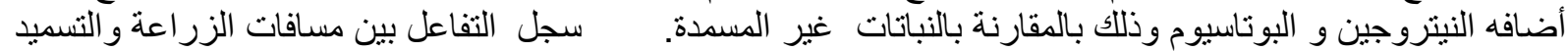

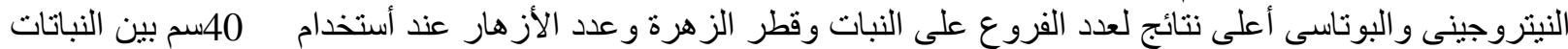

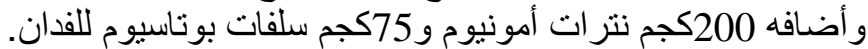

